\title{
Information Technology, Economic Growth, And Employment: Evidence From Time-Series Analyses
}

Doh-Khul Kim, (Email: dkim@meridian.msstate.edu), Mississippi State University

\begin{abstract}
Since the mid-1990s, numerous studies have shown the interactions between developments in Information Technology (IT) or the number of Internet subscribers and the general economy such as economic growth. Some show that development in IT has significantly affected growth, led by higher productivity, whereas others show no significant role of IT in the growth. Thus, no general consensus has been reached on the effects of IT development on economic (GDP) growth. By applying two popular time-series statistical tools (multivariate cointegration analysis and vector error correction model) with the total number of Internet subscribers in the U.S., this paper finds: (1) there is a long-run equilibrium linkage among the development of IT (subscriber numbers), economic growth, and employment; and (2) there are bi-directional Granger-causality relationships present between IT and economic growth, whereas there exists a uni-directional relationship between IT and employment in the U.S.
\end{abstract}

\section{INTRODUCTION}

ince the 1990s, numerous studies have shown the theoretical and empirical relationships between the development of Information Technology (IT) and economic growth, as it gains substantial research interest. Some have claimed that IT development has made significant contributions to economic growth (with higher productivity), whereas others argued there has been no significant contribution to growth by such IT development.

Using data for individual U.S. industries and industry-level production and production possibility frontier models, Jorgenson et al. (2003) show that information technology investments (coupled with higher education) have made a significant contribution to economic growth in the U.S. since 1995. Klein et al. (2003) also argue that information technology has played an important role in raising productivity growth and economic growth in the U.S. Other recent studies show the surge in productivity and economic growth in the U.S. during the late 1990s has been largely the result of the development of IT (Oliner and Sichel, 2000; Jorgenson, 2001). In a widely cited paper, Nordhaus (2001) claimed that information technology accounts for more than one-third of productivity growth in the U.S. business sector. ${ }^{1}$

However, as reported by Brynjolfsson and Hitt (2000) and Houston (2003), thus far there is lack of supporting evidence that the increase in Internet usage (or IT developments) will induce higher economic growth with better productivity. In addition, no development in the Internet and IT is expected to affect the economic growth positively unless adequate investments in education, infrastructure, and research and development follow (Edwards, 2002). A study by Houben and Kakes (2002) argues that a market-oriented financial system and a well-developed venture capital market are necessary factors if IT development is to have significant effect on economic growth. Furthermore, prior to the 1990s, numerous empirical studies (of the U.S. business sector) showed that IT made a very limited contribution to economic growth in the U.S. (Brynjolfsson, 1993; Oliner and Sichel, 1994; Jorgenson and Stiroh, 1995). 
Clearly, additional research is needed because there still is no consensus on how significantly IT development contributes to economic growth. Furthermore, a majority of the previous studies have focused on the uni-directional effect of IT on the economic growth, even though bi-directional effects between IT and economic growth can naturally be expected. In addition, this research includes the labor market dynamics by including employment for better economic interactions between IT development and real economic variables, as no previous research has taken the labor market variable into consideration.

Theoretically, the development in IT may affect not only economic growth but employment as well, and economic growth and employment may affect IT development. IT development may positively affect productivity and growth, which will eventually lead to higher employment, as such economic growth will positively affect the labor market. ${ }^{2}$ Simultaneously, such economic growth with higher employment will cause the greater IT development because of increased investment in IT. Thus, IT may Granger-cause economic growth and employment, just as growth and employment may Granger-cause IT development. ${ }^{3}$

The main purposes of this paper are to determine: (1) if there is any substantial long-run relationship present between IT development and two real economic sectors (GDP and employment); and (2) the direction of the Granger causality between the variables under consideration. To probe these questions, the study employs two popular timeseries tools (cointegration procedure and vector error correction model) that are widely used in recent time-series economic studies. The cointegration procedure can avoid any loss of valuable long-term information regarding the variables when it does not need to difference any non-stationary variables for the analyses. The vector error correction model (VECM) is also employed to identify the direction(s) of the causality of the variables by tracing the interactions of the variables from the short- to long-term. Thus, this study is expected to shed light on the correlations and interactions of the variables (IT, growth, and employment) in the U.S. economy.

This paper finds that (1) there are significant long-run relationships present between the development in IT and the two economic variables (growth and employment); and (2) there are bi-directional relationships present between IT and economic growth, whereas there exists a uni-directional relationship between IT and employment in the U.S. This paper discusses the empirical analysis and the results in Section II, and the conclusion in Section III.

\section{EMPIRICAL METHOD AND RESULTS}

\section{Data And Unit Root Test}

The quarterly data used in this study are obtained from Federal Reserve Bank of St. Louis and Jupiter Research in the U.S. The data, ranging from the first quarter of 1998 to the third quarter of 2005, are as follows: number of total subscription to high-speed Internet (as a proxy of development in the IT), nominal GDP deflated by producer price index (for GDP growth), and total employment with respect to the population (for labor market dynamics). Each variable is differenced once for the growth rate and stationarity. An augmented Dickey-Fuller test (1981) was performed to see any existence of unit roots in the levels of the variables. As table 1 illustrates, the null hypothesis of the existence of unit roots was not rejected at the level form of the data, but was rejected at the firstdifference form. Thus, all the variables have single unit roots and are cointegrated of the same order, $I(1)$, and the cointegration test can be performed without a problem. The lag lengths and the most parsimonious models with no autocorrelation for the variables are chosen following the results of Akaike's Information Criterion (AIC) and Schwartz Bayesian Criterion (SBC) tests.

\section{Cointegration Test}

A multivariate cointegration technique proposed by Johansen (1988) and Johansen and Juselius (1990) as a system-based reduced-rank regression approach is used in this study for any long-run equilibrium relationship(s) among the variables. The cointegration test is performed first because the results from that test will be used for the following vector error correction model (VECM). This Johansen and Juselius (1990) test is preferred to the simpler regression-based Engle and Granger (1987) test because it can fully capture the properties of time-series data and allows direct hypothesis testing for the coefficients of cointegrating vector(s) (Kim, 2005). 
Table 1: Augmented Dickey-Fuller Test

\begin{tabular}{|c|l|c|}
\hline Number of Subscribers & GDP & Unemployment Rate \\
\hline-0.02 & -0.21 & -1.36 \\
$(-4.76)$ & $(-5.75)$ & $(-3.95)$ \\
\hline
\end{tabular}

Notes: The numbers in parenthesis indicate t-statistics for the first differenced variables and they all reject the null hypothesis of the unit root, whereas the numbers in the upper row accept the hypothesis at a 5\% significance level. Thus, all the variables are nonstationary in levels and have the same single unit roots, $\mathbf{I}(1)$.

Table 2: Results Of Johansen Maximum Likelihood Estimation

\section{$\lambda_{\text {trace }}$ Test}

\begin{tabular}{|c|c|c|c|}
\hline Null Hypothesis & Alternative Hypothesis & $95 \%$ Critical Value & $\lambda_{\text {trace }}$ Value \\
\hline$r=0$ & $r>0$ & 29.68 & $66.32 *$ \\
\hline$r \leq 1$ & $r>1$ & 15.41 & 11.59 \\
\hline$r \leq 2$ & $r>2$ & 3.76 & 0.37 \\
\hline
\end{tabular}

$\lambda_{\max }$ Test

\begin{tabular}{|c|c|c|c|}
\hline Null Hypothesis & Alternative Hypothesis & 95\% Critical Value & $\lambda_{\max }$ Value \\
\hline$r=0$ & $r=1$ & 20.97 & $54.73^{*}$ \\
\hline$r=1$ & $r=2$ & 14.07 & 11.21 \\
\hline$r=2$ & $r=3$ & 3.76 & 0.37 \\
\hline
\end{tabular}

Notes: * denotes significance at the $5 \%$ level. $r$ denotes the number of cointegrating vectors and the $5 \%$ critical values of the maximum eigenvalue and the trace statistics are obtained from Enders' RATS Handbook (1996).

A cointegrating vector implies a long-run relationship among jointly endogenous variables. Hence, more cointegrating vectors in the model imply more stability of the system, which is composed of non-stationary variables. According to table 2, 66.32 exceeds the 95 percent critical value of the $\lambda_{\text {trace }}$ statistic (29.68) in the first panel. Thus, the null hypothesis of no cointegrating vectors can clearly be rejected, and the alternative hypothesis of one or more cointegrating vectors can be accepted. Next the $\lambda_{\text {trace }}$ (1) statistic is used to test the null of $\mathbf{r} \leq 1$ against the alternative of two or three cointegrating vectors. Because the $\lambda_{\text {trace }}(1)$ statistic of 11.59 is less than the 95 percent critical value of 15.41 , the null hypothesis is accepted this time. Therefore, it can be concluded that there is a single cointegrating vector.

Using the $\lambda_{\max }$ statistic, the null hypothesis of no cointegrating vectors $(\mathbf{r}=0)$ against the specific alternative $\mathbf{r}=1$ is clearly rejected, as the calculated value $\lambda_{\max }(0,1)=54.73$ exceeds the 95 percent critical value (20.97). To test $\mathbf{r}=1$ against the alternative of $\mathbf{r}=2$, note that the calculated value of $\lambda_{\text {max }}(1,2)$ is 11.21 , whereas the critical value at the 95 percent significance level is 14.07 . Therefore, it can be claimed that, once again, there is a single cointegrating vector. Both tests show there is one cointegrating vector present among the variables, and it can be concluded that there is a long-run equilibrium relationship (or linkage) present among IT development (represented by subscriber numbers), economic GDP growth, and employment in the U.S. 


\section{Short-Run Dynamics (With Vector Error Correction Models)}

Once the cointegrating vector is obtained from the Johansen procedure, useful information can be obtained regarding the way economic growth and employment are linked to IT development. Having the cointegrating vectors taken into account, the short-run vector autoregression in error correction model (VECM) can be expressed as follows:

$$
\begin{aligned}
& \Delta G D P_{t}=\alpha_{0}+\sum_{i=1}^{p} \alpha_{1 i} \Delta G D P_{t-i}+\sum_{i=1}^{p} \alpha_{2 i} \Delta E M P_{t-i}+ \\
& \sum_{i=1}^{p} \alpha_{3 i} \Delta I T_{t-i}+\alpha E C T_{t-1}+u_{1 t} \\
& \Delta E M P_{t}=\beta_{0}+\sum_{i=1}^{p} \beta_{1 i} \Delta G D P_{t-i}+\sum_{i=1}^{p} \beta_{2 i} \Delta E M P_{t-i}+ \\
& \sum_{i=1}^{p} \beta_{3 i} \Delta I T_{t-i}+\beta E C T_{t-1}+u_{2 t}, \\
& \Delta I T_{t}=\gamma_{0}+\sum_{i=1}^{p} \gamma_{1 i} \Delta G D P_{t-i}+\sum_{i=1}^{p} \gamma_{2 i} \Delta E M P_{t-i}+ \\
& \sum_{i=1}^{p} \gamma_{3 i} \Delta I T_{t-i}+\gamma E C T_{t-1}+u_{3 t} .
\end{aligned}
$$

where GDP is a log of total GDP (deflated by producer price index), EMP is a log of total employment, and IT is a $\log$ of total number of high speed Internet subscribers; $\alpha_{0}, \beta_{0}$ and $\gamma_{0}$ are constants indicating intercepts, respectively; $\Delta$ is a difference operator; $E C T_{t-1}$ is the error correction term obtained from the cointegration relationship that is normalized with respect to each variable; and $\alpha, \beta$ and $\gamma$ are the coefficients that show the speed of adjustment back to long-run equilibrium relationship. In addition, $\boldsymbol{u}_{1 t}, \boldsymbol{u}_{2 t}$ and $\boldsymbol{u}_{3 t}$ are serially uncorrelated random error terms with a zero mean.

The first null hypothesis is $\alpha_{3 i}=0$, implying that IT development does not Granger-cause economic growth (GDP). The second null hypothesis is $\beta_{3 i}=0$, implying that IT development does not Granger-cause employment. The last null hypothesis is $\gamma_{1 i}=\gamma_{2 i}=0$, implying economic growth and employment do not Granger-cause IT development. Even though both $t$ and $F$ tests can be used for the statistical inferences regarding the hypotheses, because all the variables in equations (1) (3) are cointegrated of the same order, the standard t-test is used for the inferences regarding individual coefficients in this study.

As table 3 shows, the coefficients of $\alpha_{3 i}$ are significantly different from zero, as the t-value of the lag 3 rejects the null hypothesis. Thus, IT development is statistically significant and Granger-causes economic growth, even though there is a three-quarter lag. ${ }^{5}$ This implies that higher numbers of Internet subscribers significantly affect the economic growth with a lag of three quarters, which is basically in line with the findings by Jorgenson (2001), with a slight difference in the level of statistical significance. However, none of the coefficients of $\beta_{3 i}$ are statistically significant, as all the t-values do not reject the null hypothesis. Hence, there is no Granger causality of IT development on employment, even though there is a positive relationship present between the two variables. The t- 
tests of $\gamma_{1 i}$ turn out to be statistically significant according to the table, which implies that economic growth positively affects IT development (or the number of Internet subscribers). Further, employment generally affects the number positively, as the t-tests of $\gamma_{2 i}$ turn out to be statistically significant for the second and third quarters. Therefore, the test shows, in the short run, there exist bi-directional Granger-causality relationships between IT development and economic growth, whereas the employment uni-directionally Granger-causes IT development in the U.S. ${ }^{6}$

Table 3: Results Of Granger Causality Test

\begin{tabular}{|c|c|c|c|c|c|c|c|}
\hline $\begin{array}{c}\begin{array}{c}\text { Dependent } \\
\text { Variable }\end{array} \\
\text { GDP }\end{array}$ & \multicolumn{7}{|c|}{ Independent Variables } \\
\hline & $\begin{array}{c}\text { GDP(1) } \\
2.23^{*} \\
{[3.67]} \\
\text { IT( }(2) \\
0.47 \\
{[0.019]}\end{array}$ & $\begin{array}{c}\text { GDP(2) } \\
1.52 \\
{[2.06]} \\
\mathrm{IT}(3) \\
3.95^{*} \\
{[3.26]}\end{array}$ & $\begin{array}{c}\text { GDP (3) } \\
2.13 \\
{[1.39]}\end{array}$ & $\begin{array}{c}\operatorname{Emp}(1) \\
0.40 \\
{[0.36]}\end{array}$ & $\begin{array}{c}\operatorname{Emp}(2) \\
0.28 \\
{[0.20]}\end{array}$ & $\begin{array}{c}\operatorname{Emp}(3) \\
3.46^{*} \\
{[3.67]}\end{array}$ & $\begin{array}{l}\operatorname{IT}(1) \\
2.94 \\
{[1.70]}\end{array}$ \\
\hline Employment & $\begin{array}{c}\text { GDP(1) } \\
1.86 \\
{[1.03]} \\
\mathrm{IT}(2) \\
0.63 \\
{[0.91]}\end{array}$ & $\begin{array}{c}\text { GDP(2) } \\
4.91^{*} \\
{[3.25]} \\
\text { IT(3) } \\
0.25 \\
{[0.73]}\end{array}$ & $\begin{array}{c}\text { GDP (3) } \\
4.35^{*} \\
{[2.96]}\end{array}$ & $\begin{array}{c}\operatorname{Emp}(1) \\
0.43 \\
{[1.33]}\end{array}$ & $\begin{array}{c}\operatorname{Emp}(2) \\
-0.22 \\
{[-0.54]}\end{array}$ & $\begin{array}{c}\operatorname{Emp}(3) \\
0.24 \\
{[0.88]}\end{array}$ & $\begin{array}{l}\operatorname{IT}(1) \\
0.53 \\
{[1.05]}\end{array}$ \\
\hline $\begin{array}{c}\text { Number } \\
\text { of } \\
\text { Subscribers } \\
\text { (IT) }\end{array}$ & $\begin{array}{c}\text { GDP(1) } \\
22.10^{*} \\
{[6.34]} \\
\text { IT }(2) \\
0.46 \\
{[0.03]}\end{array}$ & $\begin{array}{c}\text { GDP(2) } \\
17.17^{*} \\
{[4.05]} \\
\text { IT(3) } \\
0.54^{*} \\
{[7.77]}\end{array}$ & $\begin{array}{c}\text { GDP (3) } \\
31.16^{*} \\
{[3.55]}\end{array}$ & $\begin{array}{c}\operatorname{Emp}(1) \\
0.59 \\
{[0.93]}\end{array}$ & $\begin{array}{c}\operatorname{Emp}(2) \\
1.18^{*} \\
{[4.23]}\end{array}$ & $\begin{array}{c}\operatorname{Emp}(3) \\
3.82 * \\
{[7.07]}\end{array}$ & $\begin{array}{l}\mathrm{IT}(1) \\
0.53^{*} \\
{[5.46]}\end{array}$ \\
\hline
\end{tabular}

Notes: * indicates significance at the $5 \%$ level, whereas the numbers in parentheses and brackets show the lag length and t-statistics, respectively. Different lag lengths $(1,2,4)$ are also employed, but no qualitatively different results are obtained in this study.

\section{CONCLUSION}

The aim of this paper was to find the effects of IT development on the U.S. economy by focusing on the number of Internet subscribers, economic growth (GDP), and employment. To this end, a multivariate cointegration analysis was adopted to see if there exist any long-run equilibrium relationships among the variables. One cointegrating vector is found to be present. Therefore, U.S. economic growth, employment, and IT development (represented by the number of Internet subscribers) are correlated to each other in the long run. Furthermore, this study shows the direction of the effects of the variables in the short run, using the VECM procedure, which confirmed that the number of Internet subscribers significantly affects economic growth, but not employment. In addition, both economic growth and employment affect the number of high-speed Internet subscribers. Thus, it can be concluded that there exist bi-directional Granger-causality relationships between IT development and economic growth, whereas there is a uni-directional relationship present between IT and employment in the U.S. 


\section{SUGGESTIONS FOR FUTURE RESEARCH}

Even though there is no robust consensus on the effects of IT development on economic growth, more researchers show IT development has played a substantial role in positively affecting economic growth in many countries. However, those studies reached such conclusions by employing country-level data. Hence, it is worth researching if such development has any further effect on sectoral-level (such as state level) economic growth. In addition, with longer time-period data employed, any future research that shows how such IT development affects sectoral-level economy will provide significant information for state government and policy makers.

\section{ENDNOTES}

1. These studies found e-commerce has made a very small contribution to U.S. economic growth.

2. It is implicitly assumed that the growth effect is greater than the productivity effect in IT development's affecting on the labor market.

3. Granger (1969) proposed a concept of causality based upon prediction error. Variable $\mathrm{X}$ is said to Grangercause variable $\mathrm{Y}$ if $\mathrm{Y}$ can be forecast better using past $\mathrm{Y}$ and past $\mathrm{X}$ than just past $\mathrm{Y}$. If $\mathrm{X}$ does not improve the forecasting performance of Y, then X does not Granger-cause Y.

4. Once again, the lag lengths $(p)$ are properly chosen following the results of the AIC and SBC tests.

5. The effects of GDP and employment (with lags) on the GDP and employment are not discussed here, as it is beyond the main purpose of this study.

6. Using both White's (1980) and Lagrange Multiplier (LM) tests, standard diagnostic tests are also performed for heteroscedasticity and serial correlation, respectively. No problems are found on these diagnostic tests for proper specification of the model.

\section{REFERENCES}

1. Brynjolfsson, E., The Productivity Paradox of Information Technology, Communications of the ACM, Vol. 12, pp. 67-77, 1993.

2. Brynjolfsson, E. and Hitt, L. M., Beyond Computation: Information Technology, Organizational Transformation, and Business Performance, Journal of Economic Perspectives, Vol. 14, No. 4, pp. 23-48, 2000.

3. Dickey, D. A. and Fuller, W. A., Likelihood Ratio Statistics for Autoregressive Time Series with a Unit Root, Econometrica, Vol. 49, No. 4, pp. 1057-72, 1981.

4. Dickey, D., Jansen, D., and Thornton, D., A Primer on Cointegration with an Application to Money and Income, Review of Federal Reserve Bank of St. Louis, Vol. 73, No. 2, pp. 58-78, 1991.

5. Edwards, S., Information Technology and Economic Growth in Developing Countries, Challenge, Vol. 45, No. 3, pp. 19-43, 2002.

6. $\quad$ Enders, W., Applied Econometric Time Series, John Wiley \& Sons, Inc., 1995.

7. $\quad$ Enders, W., RATS Handbook for Econometric Time Series, John Wiley \& Sons, Inc., 1996.

8. Engle, R. F. and Granger, C. W. J., Cointegration and Error Correction: Representation, Estimation, and Testing, Econometrica, Vol. 55, No. 2, pp. 251-76, 1987.

9. Granger, C. W. J., Investigating Causal Relationships by Econometric Models and Cross Spectral Models, Econometrica, Vol. 37, No. 3, pp. 424-38, 1969.

10. Houben, A. and Kakes, J., ICT Innovations and Economic Performance: the Role of Financial Intermediation, KYKLOS, Vol. 55, No. 4, pp. 543-62, 2002.

11. Houston, D. A., Can the Internet Promote Open Global Societies?, Independent Review, Vol. 7, No. 3, pp. 353-369, 2003.

12. Johansen, S., Statistical Analysis of Cointegration Vectors, Journal of Economic Dynamics and Control, Vol. 12, No. 2/3, pp. 231-54, 1988.

13. Johansen, S. and Juselius, K., Maximum Likelihood Estimation and Inference on Cointegration - with Applications to the Demand for Money, Oxford Bulletin of Economic and Statistics, Vol. 52, No. 2, pp. 169$210,1990$. 
14. Jorgenson, D. W., Information Technology and the U.S. Economy, American Economic Review, Vol. 91, No. 1, pp. 1-32, 2001.

15. Jorgenson, D. W., Ho, M. S. and Stiroh K. J., Growth of US Industries and Investments in Information Technology and Higher Education, Economic Systems Research, Vol. 15, No. 3, pp. 279-325, 2003.

16. Jorgenson, D. W. and Stiroh, W., Computers and Growth, Economics of Innovation and New Technology, Vol. 3, No. 3-4, pp. 295-316, 1995.

17. Information Technology and Growth, American Economic Review, Vol. 89, No. 2, pp. 109-15, 1999.

18. Kim, D. K., Unionization, Unemployment and Growth in Korea - A Cointegration Approach, Atlantic Economic Journal, Vol. 33, No. 2, pp. 225-33, 2005.

19. Klein, L. R., Saltzman, C., and Duggal V. G., Information Technology and Productivity - The Case of the Financial Sector, Survey of Current Business, Vol. 83, No. 8, pp. 32-37, 2003.

20. Nordhaus, W. D., New Data and Output Concepts for Understanding Productivity Trends, NBER Working Paper 8097, National Bureau of Economic Research, Inc., Cambridge, MA, 2001.

21. Oliner, S. D. and Sichel, D. E., Computers and Output Growth Revisited: How Big Is the Puzzle? Brooking Papers on Economic Activity, Vol. 0, No. 2, pp. 273-317, 1994.

22. The Resurgence of Growth in the Late 1990s: Is Information Technology the Story? Journal of Economic Perspectives, Vol. 14, No. 4, pp. 3-22, 2000.

23. White, H., A Heteroskedasticity - Consistent Covariance Matrix and a Direct Test for Heteroskedasticity, Econometrica, Vol. 48, No. 4, pp. 817-38, 1980. 


\section{NOTES}

